\title{
Concentrations of Chemical Elements in Different Tree Compartments Grown in a Mixed Dipterocarp Forest in Sarawak, Malaysia
}

\author{
Gerhard BREULMANN United Graduate School of Agricultural Sciences, Ehime University, \\ Matsuyama 790, Ehime, Japan \\ Ikuo NinOMIYA College of Agriculture, Ehime University, Matsuyama 790, Ehime, Japan \\ Kazuhiko OGINO College of Agriculture, Ehime University, Matsuyama 790, Ehime, Japan
}

\begin{abstract}
The distribution of mineral elements in different compartments of trees grown in a mixed dipterocarp forest in the Lambir Hills National Park, Miri, Sarawak was studied. 514 samples mainly of leaves, twigs and trunks, partly of roots, barks and litter were collected from 101 different trees of 62 species of 25 families. The samples were analyzed for 28 chemical elements, i.e. $\mathrm{N}, \mathrm{K}, \mathrm{Ca}, \mathrm{Mg}, \mathrm{Mn}, \mathrm{Na}$, $\mathrm{Al}, \mathrm{Br}, \mathrm{Fe}, \mathrm{B}, \mathrm{Sr}, \mathrm{Ba}, \mathrm{Zn}, \mathrm{Rb}, \mathrm{Cu}, \mathrm{Ni}, \mathrm{Co}, \mathrm{Ti}, \mathrm{Sc}, \mathrm{Cr}, \mathrm{Pb}, \mathrm{Ce}, \mathrm{Li}, \mathrm{As}, \mathrm{Cs}, \mathrm{V}, \mathrm{Mo}$ and Th. Essential elements as $\mathrm{N}, \mathrm{K}, \mathrm{Mg}, \mathrm{Mn}, \mathrm{Fe}, \mathrm{B}$ and $\mathrm{Ni}$ showed higher concentrations in the leaves. $\mathrm{Ca}, \mathrm{Zn}$ and $\mathrm{Cu}$ were found significantly higher in the twigs. These elements are known to be related to the auxin metabolism effective to the induction of the cell lignification. The elements with no characteristic concern to any physiological processes behaved as if they underwent passive uptake. The uptake of elements with toxic or negative effects to plants, e.g., $\mathrm{Al}, \mathrm{Pb}$ or As seemed to be either blocked by the roots or they were safely stored in those organs as trunks and barks. Taken the fact into account that those elements actively associated with plant physiological processes are accumulated in the living plant organs, due attention should be paid to the high concentrations of Ba (Gluta oba), Co (Koilodepas laevigatum, Trigonostemon capillipes, Allantospermum borneense) or $\mathrm{Sr}$ (Koilodepas laevigatum).
\end{abstract}

Key Words: mineral elements / different compartments / accumulation / dipterocarp forest / Sarawak

The distribution of mineral elements in trees of tropical rain forests was reported by several authors (Ashton, 1982; Golley et al., 1975). In view of plant physiological studies leaves are the active and important part of a plant (Vitousek \& Sanford, 1986). They work as matter producing factory. But for studies of quantitative accumulations of chemical elements, due attention to the balance between the leaves and stems should be paid, as they represent short- and long-nutrient cycling, respectively (Jayasekera, 1994). Studies of chemical elements in tropical trees were so far mainly restricted to the essential elements, the macro- and micro-nutrients. Some authors (Horovitz, 1988; Markert, 1991) suggested that the metabolic role of several elements has not yet been well recognized and the classification into essential and nonessential elements requires continuous revision. The list of essential micronutrients has expanded as we have become more aware of the biochemistry of physiological processes. Given that only 300 species of the 500,000 or more plant species have been studied on their nutrient requirements, the present list of plant micronutrients is expanding and may well continue to expand in the future. $\mathrm{Ni}$, for example, was added to the list of micronutrients as late as 1992 (Perry, 1994).

The canopies of tropical rain forests are too tall to reach for direct observations or sampling of leaves. In the Lambir Hills National Park, Sarawak, a walkway system was constructed through forest 


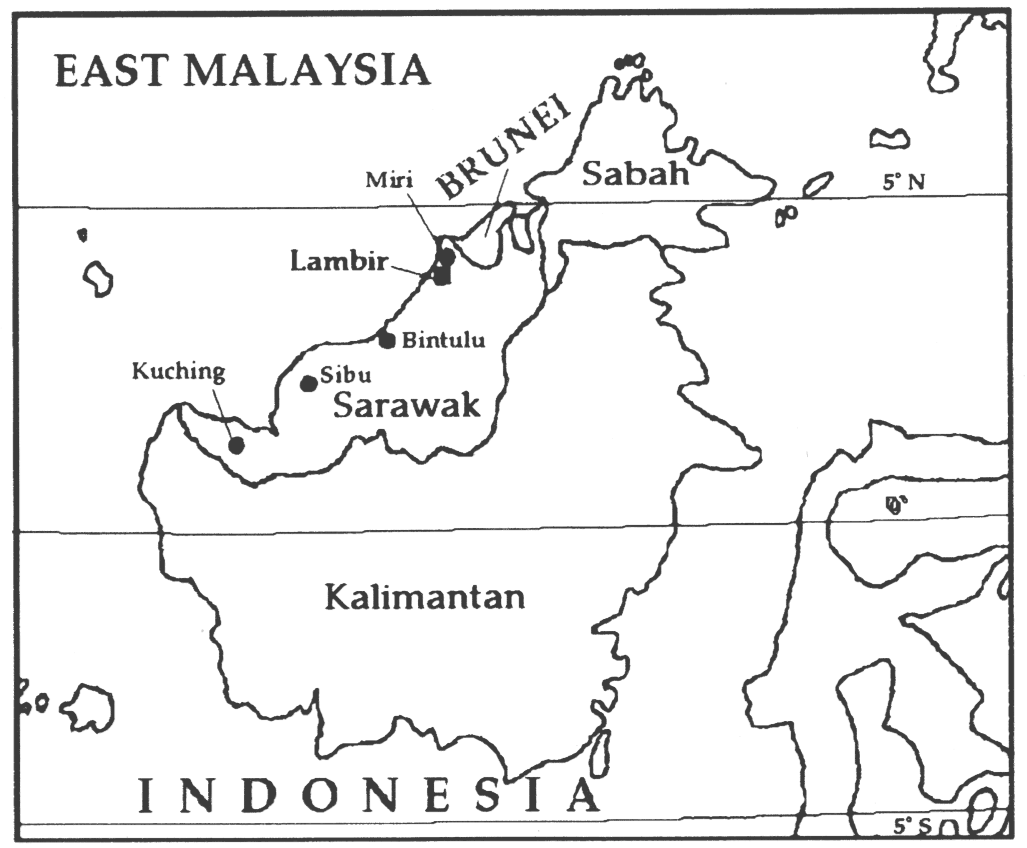

Fig. 1. Location of the Lambir Hills National Park in the north east of Sarawak, Malaysia.

canopy in 1992 to provide an easy access to the leaves and twigs of tropical rain forest.

In the present study 514 samples of different compartments, mainly of leaves, twigs and trunks, partly of barks, roots and litter, from 101 individual trees of 62 species of 25 families were collected. The identification is still tentative, plant names are subject to further examination. Analyzed were 28 chemical elements as given in Figure 2. The vascular plants develop a system of multiple functions of physiological processes. The root hairs absorb the mineral elements, the vascular system transports them and the living cells in the leaves utilize them. To clarify the distribution characteristics of various chemical elements over the compartments, due attention to the physiological function of each compartment should be paid.

\section{MATERIALS AND METHODS}

The Lambir Hills National Park $\left(4^{\circ} 2^{\prime} \mathrm{N}, 113^{\circ} 50^{\prime} \mathrm{E}\right)$ is located in the north east of Sarawak, about 30 $\mathrm{km}$ south of Miri (Figure 1) and covers an area of 6949 ha. All samples were collected in the central part of a research plot, specifically designed for canopy biology studies. A detailed description of location, sampling procedure and analyses was given in Breulmann et al., (1996).

In total 514 samples were collected from canopy trees as well as from understory trees. The obtained concentrations of the samples from the same tree and compartment but different heights and sampling occasions were averaged. For several elements we performed two measurements for the same sample (Breulmann et al., 1996). We averaged these values when the deviation between the two was less than $10 \%$. In case the deviation exceeded $10 \%$, one value was selected referring to the value of the Standard Reference Material. The statistical analyses were performed by SPSS. Because the number of collected samples of barks, roots and litter was small, only the means were calculated in order to show the general trend of the element distributions in these compartments. 


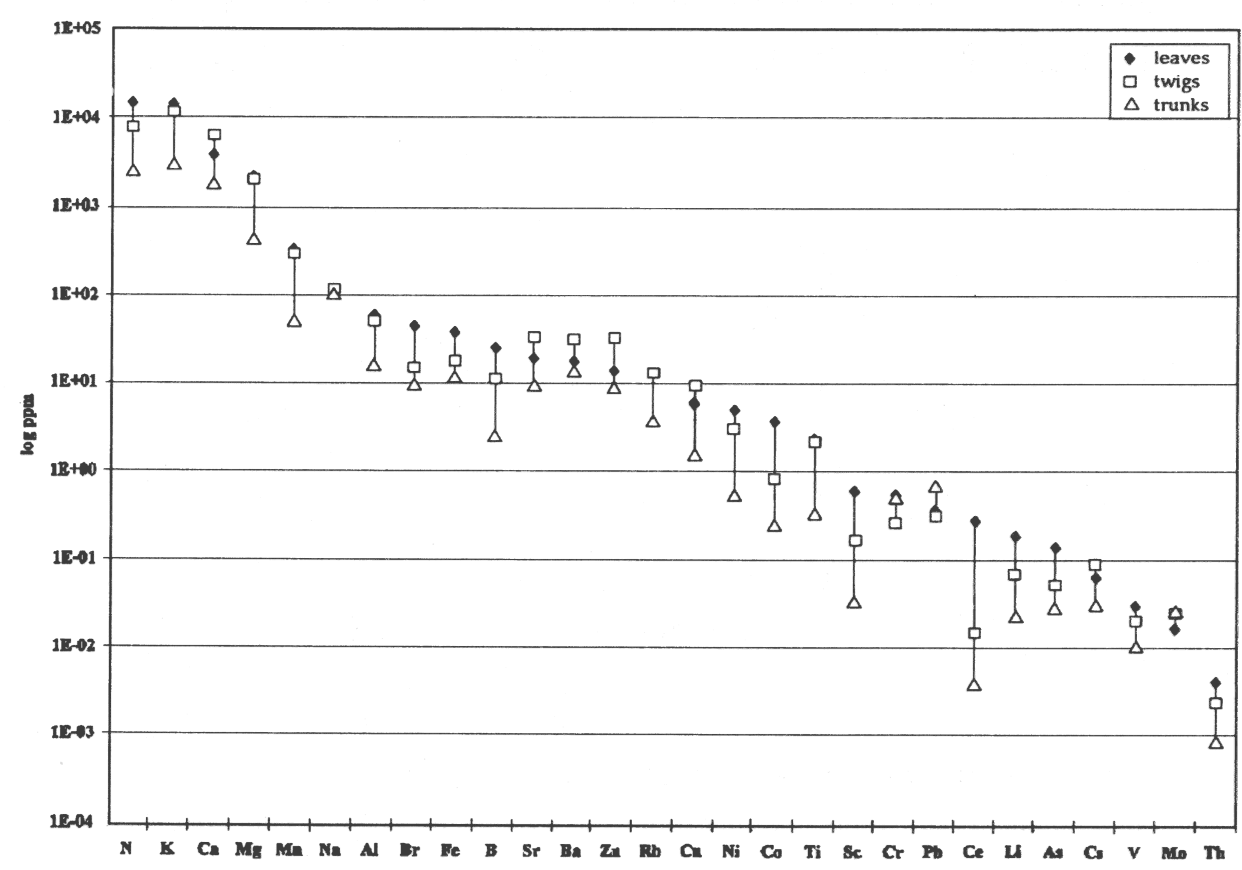

Fig. 2. Mean values of the element concentrations of the leaves, twigs and trunks.

\section{RESULTS}

\section{Concentrations of chemical elements in leaves, twigs and trunks}

Figure 2 illustrates the element concentrations of the compartments leaves, twigs and trunks. The figures of the means are given in the Appendix. In each column, compartments sharing the same letter were not statistically significant different at the $1 \%$ level. $\mathrm{N}$ and $\mathrm{K}$ showed significantly higher concentrations in the leaves. They have a primary function in living tissues. Ca was found significantly higher in the twigs. It is known as electrolytic element as well as a structural component of the middle lamella (Perry, 1994). Mg, Mn, Na, Al, Rb, Ti, Pb, Ce and Mo showed no significant differences between the leaves and twigs. Other elements, i.e., $\mathrm{Br}, \mathrm{Fe}, \mathrm{B}, \mathrm{Ni}, \mathrm{Co}, \mathrm{Sc}, \mathrm{Cr}, \mathrm{Li}, \mathrm{As}, \mathrm{V}$ and Th showed significantly higher concentrations in the leaves, while $\mathrm{Sr}, \mathrm{Ba}, \mathrm{Zn}, \mathrm{Cu}$ and $\mathrm{Cs}$ were higher in the twigs.

The concentrations in the trunks were determined in 51 trees. Cr showed a similar concentration in the trunks and the leaves. $\mathrm{Pb}$ showed the highest mean concentration in the trunks. It is not essential for plants and the translocation from the roots is reported as very slow (Streit \& Stumm, 1993). All other elements showed significantly lower concentrations in the trunks, except Mo (Figure 2).

Several species showed accumulative tendencies for certain elements in the leaves (Breulmann et al., 1996). Most species reflected such a tendency to the twigs but not always to the trunks (Table 1). The accumulations of $\mathrm{K}, \mathrm{Ni}$ and Co of Trigonostemon capillipes (Euphorbiaceae) were reflected to the twigs but not to the trunks, however the twigs showed an accumulation of $\mathrm{Zn}$ (84.16 - $173.09 \mathrm{ppm}$ ) and the trunks of $\mathrm{Na}(265-645.6 \mathrm{ppm}) . \mathrm{Zn}$ is essential as a coenzyme in different reactions, e.g., chlorophyll synthesis (Markert, 1993) and auxin metabolism (Berrie et al., 1987). Na is regarded as essential' only for C4 - plants (Borriss \& Libbert, 1984). However, many tree species accumulate high levels of $\mathrm{Na}$, although in most cases, $\mathrm{Na}$ has no clear physiological function (Perry, 1994). Gluta oba (Anacardiaceae) and Mallotus sp. (Euphorbiaceae) reflected the accumulations of Ba and $\mathrm{Mn}$, 
Table 1. List of tree species showing an accumulative characteristic. The letters indicate in which compartment the accumulations were reflected. $I=$ leaves, $t=t$ wigs, $t r=t$ trunks.

\begin{tabular}{|c|c|c|c|c|c|c|c|c|c|c|c|}
\hline Species & Family & $\mathrm{K}$ & $\mathrm{Ca}$ & $\mathrm{Mn}$ & $\mathrm{Na}$ & $\mathrm{Ba}$ & $\mathrm{Zn}$ & $\mathrm{Sr}$ & $\mathrm{Ni}$ & Co & $\mathrm{Al}$ \\
\hline Gluta oba $(\mathrm{n}=2)$ & Anacardiaceae & & & & & $1, \mathrm{t}$. & & & & & \\
\hline Koilodepas laevigatum $(\mathrm{n}=8)$ & Euphorbiaceae & & $1, \mathrm{t}, \mathrm{tr}$ & & & & & $1, t, \operatorname{tr}$ & & & \\
\hline Mallotus sp. $(\mathrm{n}=2)$ & Euphorbiaceae & & & $1, \mathrm{t},{ }^{*}$ & & & & & & & \\
\hline Trigonostemon capillipes $(n=7)$ & Euphorbiaceae & $1, \mathrm{t}$ & & & $\operatorname{tr}$ & & $\mathrm{t}$ & & $1, \mathrm{t}$ & $1, \mathrm{t}$ & \\
\hline Allantospermum borneense $(\mathrm{n}=2)$ & Ixonanthaceae & & & & & & & & & $\mathrm{l}, \mathrm{t}$ & \\
\hline Memecylon sp. $(\mathrm{n}=\mathrm{l})$ & Melastomataceae & & & & & & & & & & $1, t, \operatorname{tr}$ \\
\hline
\end{tabular}

* accumulation corresponds with findings of Masunaga et al., (1995); Markert (1993)

${ }^{\star \star}$ no trunk samples collected

respectively, in the twigs. Trunk samples were not collected. Koilodepas laevigatum (Euphorbiaceae) accumulated $\mathrm{Ca}$ and $\mathrm{Sr}$ in all compartments, while $\mathrm{Co}$ was accumulated only in the leaves. Allantospermum borneense (Ixonanthaceae) showed the accumulative tendency for Co in leaves and twigs. The accumulation of $\mathrm{Al}$ by Memecylon sp. corresponded with Masunaga et al., (1995) and Markert (1993).

\section{Concentrations of chemical elements in barks, roots and leaf-litter}

From the compartments barks, roots, and leaf-litter the number of samples collected was small. The means of the concentrations are given in the Appendix. Figure 3 shows the comparison of the means of the barks, roots and litter to the means of all 514 samples, taken as the base-line. The relative deviation was given in percentage.

The barks showed negative deviations for all essential elements but Fe. This suggested that the bark function is less remarkable in plant physiology. High positive deviations were found only for $\mathrm{V}$ and Th.

The roots showed high positive deviations of $\mathrm{Al}, \mathrm{Fe}, \mathrm{Pb}, \mathrm{As}, \mathrm{V}$ and $\mathrm{Th} . \mathrm{Al}$ and $\mathrm{Fe}$ are reported to show higher concentrations in the roots (Hoffmann, 1982), as they occur in relatively higher concentrations in the soil solution under acidic conditions.

The leaf-litter samples showed high positive deviations for $\mathrm{Br}$ and As. Essential elements in the leaf-litter samples were found more or less within the range of the overall means, except $\mathrm{K}$, which showed a negative deviation.

\section{DISCUSSION}

\section{Accumulations of chemical elements into different compartments}

The process of assimilation occurring in a plant undergoes complex biochemical reactions. The mineral nutrients are translocated to the various parts of a plant for utilization in various biological functions. For example, nitrate $\left(\mathrm{NO}_{3}{ }^{-}\right)$is reduced to ammonia $\left(\mathrm{NH}_{3}\right)$, then introduced into the intermediary metabolism through a series of enzyme-mediated steps (Taiz \& Zeiger, 1991). Other elements, especially those rated as macro- and micro-nutrient cations, are taken up by plants forming complexes with organic compounds, e.g., $\mathrm{Ca}^{2+}$-pectate associated with the cell wall. It is widely accepted that chemical elements occur in the greatest concentrations in the living tissues, e.g., foliage, cambial layers, growing root tips, etc., and in the lowest concentrations in the woody stem. Perry (1994) gave base-line data for element concentrations in small branches and small roots to be $50-70 \%$ of those accumulated in the foliage, large branches and roots to be $20-30 \%$ and stems to be $10-20 \%$. Our data of mineral concentrations in the leaves, twigs and trunks, as given in the Appendix follow this trend in general. 

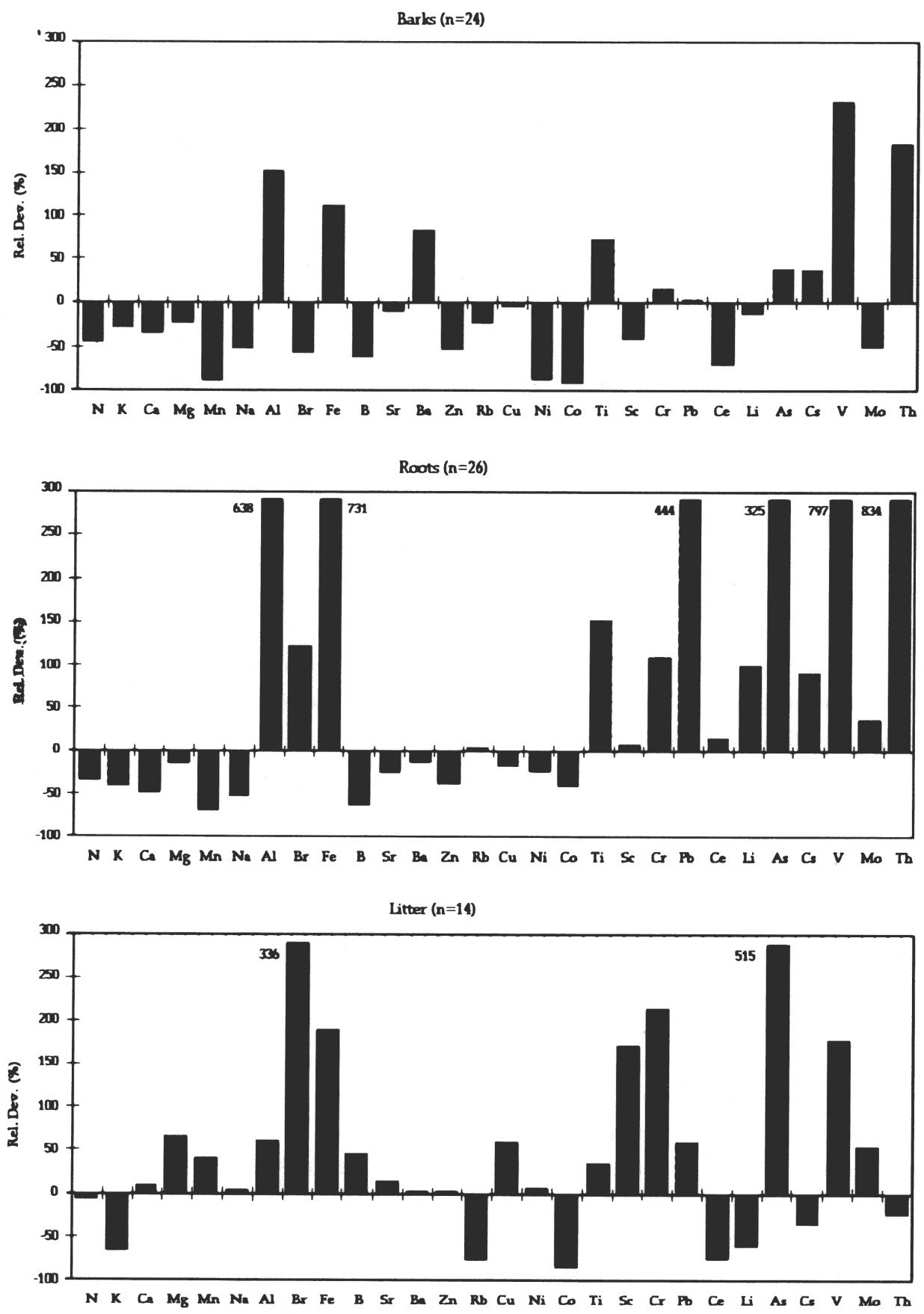

Fig. 3. Mean values of the element concentrations of the barks, roots and litter in comparison with the means of all 514 samples taken as the base-line.

\section{Functions of chemical elements in plants}

$\mathrm{N}$ is known as a very important element in the physiologically active compounds present in plant cells (Taiz \& Zeiger, 1991). It is an element compulsory in forming proteins, nucleic acids and other nitrogen-containing components of the cell (Berrie et al., 1987). N normally does not occur in the structural components of plants, it is readily remobilized from aging organs. $\mathrm{K}$ also is involved in numerous physiological functions, e.g., osmotic regulation, stomatal movement or photosynthate 
transportation.

$\mathrm{Ca}$ is required as an electrolytic and as a structural element. It acts as a coenzyme and is a constituent of the middle lamella (Berrie et al., 1987). It is also required for the cell elongation and is possibly related to the auxin action (Taiz \& Zeiger, 1991). Among the micronutrients, $\mathrm{Zn}$ is involved in the chlorophyll synthesis and the auxin metabolism (Berrie et al., 1987). Cu containing enzymes hold key positions in lignification, protein synthesis and auxin regulation (DKI, 1988). The biological effect of auxin is said to promote or inhibit cell elongation (Berrie et al., 1987), but it also induces the lignification of cells (Borriss \& Libbert, 1984). The higher concentrations of $\mathrm{Ca}, \mathrm{Zn}$ and $\mathrm{Cu}$ in the twigs might be related to the auxin production and lignification.

$\mathrm{Fe}, \mathrm{Mn}, \mathrm{Mo}$ and Ni are essential for certain enzyme activities (Perry, 1994). Fe and Mn, which readily change their valence state, mediate electron transfer within cells. $\mathrm{Fe}$ is also an essential constituent of the cytochrome system. Mo is involved in the nitrogen metabolism. It can be toxic to grazing animals at a level not toxic for plants (Streit \& Stumm, 1994). Ni is related to N-fixation and in some plants it is a constituent of Urease (Markert, 1993). The function of B is still unknown (Perry, 1994). The translocation rate of Fe, Mo, Ni and B is reported as low to moderate. Mn is translocated easily (Borriss \& Libbert, 1984; Streit \& Stumm, 1993). The uptake rate of all these elements is promoted by low $\mathrm{pH}$ values.

The status of Co as a micro-nutrient is not yet certain, however, it has been shown, that deficiency of Co can lead to chlorosis and leaf-drop (Berrie et al., 1987). It is also counted as a necessary element in the N-fixation of symbiotic Rhizobium bacteria. Na is not regarded as essential or necessary, however, it is accumulated at high levels by many tree species (Perry, 1994). Sr can be used as a substitute for K and $\mathrm{Ca}$ when these elements are short (Kimmins, 1987). Al is regarded as toxic in high concentrations, especially in the rhizosphere (Ulrich, 1981).

\section{Compartments as a reflection of element functions}

As the mineral concentrations in the different compartments of the rain forest trees of the Lambir Hills National Park followed the trend discussed by Perry (1994), the concentrations of $\mathrm{N}, \mathrm{K}, \mathrm{Mg}, \mathrm{Mn}, \mathrm{Fe}$, $\mathrm{B}$ and $\mathrm{Ni}$ in the leaves were higher and became lower to the twigs and trunks. $\mathrm{Ca}, \mathrm{Zn}$ and $\mathrm{Cu}$ showed significantly higher concentrations in the twigs.

The concentrations of physiologically active elements were comparatively low in the trunks. This may reflect the trunks main function as a storage organ, composed largely of dead cells. They showed remarkably higher concentrations of $\mathrm{Pb}$ whose translocation rate from the roots is said very slow (Streit \& Stumm, 1993). Co is accumulated in the vegetative parts and less in the storage organs (Streit \& Stumm, 1993), which corresponded well to our results (Appendix). This can be regarded as element specific characteristic.

The barks showed negative deviations for all essential elements but Fe (Figure 3). The barks seemed less physiologically active than any other parts of a plant. High positive deviations were recorded for $\mathrm{V}$ and $\mathrm{Th}$. But not much is known of these elements' uptake and distribution.

The roots showed positive deviations for $\mathrm{Al}, \mathrm{Fe}, \mathrm{Pb}, \mathrm{As}, \mathrm{V}$ and $\mathrm{Th}$ (Figure 3). $\mathrm{Al}$ and $\mathrm{Fe}$ occur relatively high in the soil under acidic conditions (Scheffer \& Schachtschabel, 1989). The soil pH in the Lambir Hills National Park was reported as ranging between 4.2 and 5.2 (Hirai et al., 1995). Nultsch (1982) reported that in front of the endodermis congestions of $\mathrm{Al}$ were observed frequently. It probably is because the Casparian bands build a barrier to $\mathrm{Al}$-inflow. The uptake of $\mathrm{Pb}$ and As seems to be passive (Streit \& Stumm, 1993). The Pb translocation rate from the roots to other plant parts is low. Arsenic is translocated to many other plant parts, however, high concentrations are normally 
found in the roots (Streit \& Stumm, 1993).

In the leaf-litter $\mathrm{Br}$ and $\mathrm{As}$ showed positive deviations (Figure 3). The reason for this positive deviations was not clarified yet. $\mathrm{K}$ showed a negative deviation. Leaching might be a cause.

From what was found from the element concentrations in the different compartments, it was verified that those elements associated with physiological processes were positively taken up and accumulated in the living organs of a plant. The elements with no characteristic concern to any physiological process behaved as if they underwent passive uptake. While the elements toxic or with negative effect to a plant may be absorbed, but their invasion into the plant body was inhibited or they were transported to those organs as trunks and barks for safe storage.

\section{Specific characteristics of element accumulations}

Out of 62 species, several species showed specific characteristics of accumulations to certain elements as shown in Table 1. In case of Co three species, e.g., Koilodepas laevigatum, Trigonostemon capillipes and Allantospermum borneense were determined as accumulators. But the three species did not accumulate into the trunks. $\mathrm{Ca}$ and $\mathrm{Sr}$ were accumulated by Koilodepas laevigatum in all three compartments. Gluta oba and Mallotus sp. accumulated $\mathrm{Ba}$ and $\mathrm{Mn}$, respectively. These accumulations took place in the leaves and twigs. Trunk samples were not collected from those species. Trigonostemon capillipes accumulated $\mathrm{K}, \mathrm{Na}, \mathrm{Zn}, \mathrm{Ni}$ and $\mathrm{Co}$. $\mathrm{K}, \mathrm{Ni}$ and $\mathrm{Co}$ were accumulated in the leaves and twigs. The accumulation of $\mathrm{Na}$ and $\mathrm{Zn}$ took place only in the trunks and twigs, respectively. In case of Memecylon sp. the accumulation of $\mathrm{Al}$ in all compartments corresponded with Masunaga et al., (1995) and Markert (1993).

Generally speaking an accumulation can not be equated with a physiological benefit for the organism (Markert, 1992). Some of the trees of the Lambir Hills National Park showed such an anomaly or specific characteristic of element accumulation to certain compartments. Little is known yet on such specific anomaly, its causes, its functions or its results. However, it is important to remember that organisms are quite diverse and highly adaptive in their nutrient requirements and particularly in their tolerances (Perry, 1994). We do not know again the richness of biodiversity of component tree species of tropical rain forests. But the results of our study of element accumulations by various tree species to different compartments gave a suggestion to clarify the functions and results of biodiversity. Due attention should be paid to the genetic variation of the inter- and intra-population in relation to plant function, requirements for nutrients and uptake. It may give us an important key of niche and specific differentiation as discussed by Ernst (1990).

ACKNOWLEDGEMENTS Our profound thanks are due to Prof. P. S. Ashton, Harvard University, Datuk Leo Chai and Hua Seng Lee, Forest Department of Sarawak and Emeritus Prof. S. Tamura, University of Tokyo for the project organization. We are also grateful to Dr. T. Yamakura, Osaka City University, Prof. T. Inoue, Kyoto University, Dr. T. Ohkubo, Utsunomiya University and the field staff of the Forest Department of Sarawak for their support in field works. Thanks also to Dr. K. Nishimura, Kyoto University, Dr. K. Sakurai, Kochi University, Prof. Dr. B. Markert, Internationales Hochschulinstitut Zittau (IHI), Prof. Dr. A. Kratochvil, Universitaet Osnabrueck and Mrs. U. Leffler, IHI, for their support in laboratory works.

\section{REFERENCES}

Ashton, P. S. 1982. Dipterocarpaceae. In:: van Steenis, C. G. G. J., Flora Malesiana, ser. 1, 9: 237- 
552.

Berrie, G. K., Berrie, A. \& Eze, J. M. O. 1987. Tropical Plant Science, 163-166. Longman Group, Hong Kong.

Borriss, H. \& Libbert, E. 1984. Pflanzenphysiologie, 591 pp. Gustav Fischer Verlag, Jena

Breulmann, G., Ninomiya, I. \& Ogino, K. 1996. Distribution characteristics of chemical elements in leaves of trees of a mixed dipterocarp forest in Sarawak, Malaysia. Tropics 6: 29-38.

DKI (Deutsches Kupfer-Institut), 1988. Kupfer in der Landwirtschaft, 1. Auflage. Deutsches KupferInstitut, Berlin.

Ernst, W. H. O. 1990. Element allocation and (re)translocation in plants and its impacts on representative sampling. In: Markert, B. \& Lieth, H., eds., Element Concentration Cadasters in Ecosystems, 17-40. VCH, Weinheim.

Golley, F. B., McGinnis, J. T., Clements, R. G., Child, G. \& Duever, M. J. 1975. Mineral Cycling in a Tropical Moist Forest Ecosystem, 248 pp. Univ. Georgia Press, Athens.

Hirai, H., Matsumura, H., Hirotani, H. \& Sakurai, K. 1995. Soils and the distribution of Dryobalanops aromatica and D. lanceolata in mixed dipterocarp forest - A case study at Lambir Hills National Park, Sarawak, Malaysia. In: Lee, H. S., Ashton, P. S. \& Ogino, K., eds., Long Term Ecological Research of Tropical Rain Forest in Sarawak II-3: 92-109.

Hoffmann, G. 1982. Zusammenhaenge zwischen kritischen Schadstoffgehalten im Boden, in Futterund Nahrungspflanzen. Landwirtschaftliche Forschung, Sonderheft 39: 130-153.

Horovitz, C. T. 1988. Is the major part of the periodic system really inessential for life? J. Trace Elem. Electrolytes Health 2: 135-144

Jayasekera, R. 1994. Sampling of tropical terrestrial plants with particular reference to the determination of trace elements. In: Markert, B., ed., Environmental Sampling for Trace Analysis, 443-447. VCH, Weinheim.

Kimmins, J. P. 1987. Forest Ecology, 68-129. Collier Macmillan, Canada.

Markert, B. 1991. Multi-element analysis in plants - Analytical tools and biological questions. In: Adriano, D. C. ed., Biogeochemistry of Trace Metals, 401-428. Lewis Publishers, Boca Raton.

1992. Presence and significance of naturally occurring chemical elements of the periodic system in the plant organism and consequences for future investigations on inorganic environmental chemistry in ecosystems. Vegetatio 103: 1-30.

_. 1993. Instrumentelle Multielementanalyse von Pflanzenproben, $265 \mathrm{pp}$. VCH, Weinheim.

Masunaga, T., Kubota, D., Rasyidin, A., Hotta, M. \& Wakatsuki, T. 1995. Distribution characteristics of mineral elements in trees of tropical rain forest, West Sumatra, Indonesia. In: Schulte, A., Ruhiyat, D., eds., Proceedings International Congress on Soils of Tropical Forest Ecosystems, 3rd Conference on Forest Soils, Balikpapan, Indonesia 6, 101-121. Mulawarman University Press, Indonesia

Nultsch, W. Allgemeine Botanik,. 7. Auflage. 516 pp. Thieme Verlag, Stuttgart.

Perry, D. A. 1994. Forest Ecosystems, 339-359. The Johns Hopkins University Press, Baltimore, London.

Scheffer, F. \& Schachtschabel, P. 1989. Lehrbuch der Bodenkunde, 12., neu bearbeitete Auflage, 491 pp. Ferdinand Enke Verlag, Stuttgart.

Streit, B. \& Stumm, W. 1993. Chemical properties of metals and the process of bioaccumulation in terrestrial plants. In: Markert, B., ed., Plants as Biomonitors, 31-62. VCH, Weinheim.

Taiz, L. \& Zeiger, E. 1991. Plant Physiology, 565 pp. Benjamin/Cummings Publishing Company, Inc., California. 
Ulrich, B. 1981. Destabilisierung von Waldoekosystemen durch Akkumulation von Luftverunreinigungen. Forst- und Holzwirt 36 (21): 525-532.

Vitousek, P. M. \& Sanford, R. L. 1986. Annual Review of Ecology and Systematics 17: 137-167.

Received April 28, 1996

Accepted July 10, 1996

\section{G. BREULMANN, 二宮生夫, 荻野和彦 サラワク混交フタバガキ林に生育する樹木 の各部位における化学元素濃度の分布}

マレーシア連邦サラワク州にあるランビル国立公園の, 混交フタバガキ林に生育する樹木の異なった部位 における無機元素濃度分布を調べた。25 科 62 種 101 個体の葉, 梢端付近の小枝, 幹, 根から 514 個のサ ンプルを採集した。構成元素の分析は $\mathrm{N}, \mathrm{K}, \mathrm{Ca}, \mathrm{Mg}, \mathrm{Mn}, \mathrm{Na}, \mathrm{Al}, \mathrm{Br}, \mathrm{Fe}, \mathrm{B}, \mathrm{Sr}, \mathrm{Ba}, \mathrm{Zn}, \mathrm{Rb}, \mathrm{Cu}, \mathrm{Ni}, \mathrm{Co}, \mathrm{Ti}$ ， $\mathrm{Sc}, \mathrm{Cr}, \mathrm{Pb}, \mathrm{Ce}$, Li, As, Cs, V, Mo およびTh の 28 種についておこなつた。このうち必須元素である N, K, $\mathrm{Mg}, \mathrm{Mn}, \mathrm{Fe}, \mathrm{B}$ および $\mathrm{Ni}$ はとくに葉に高濃度の蓄積がみとめられた。Ca, Zn および Cu については梢端 付近の小枝で有意に高い濃度を示した。これらの元素は, 細胞の木化の誘導に影響を及ぼす植物ホルモン であるオーキシンの代謝に関係していることが知られている。これに対して，いずれの生理過程にも特徴 的な影響をもたないような元素は受動的な取り込みというべき濃度分布を示した。植物にとって有毒もし くは生育に負の影響をもつ元素, 例えば $\mathrm{Al}, \mathrm{Pb}, \mathrm{As}$ などは根の部分で吸収を遮断されたり, 幹や樹皮など の組織に安全な形で貯蔵されるようにみえた。植物の生理過程に積極的に影響を及ぼす元素が植物の生き た組織に蓄積されているという事実から，Gluta oba にBa が, Koilodepas laevigatum, Trigonostemon capillipes, Allantospermum borneense にCo が, Koilodepas laevigatum にSr が高濃度に集積されるという事 実はこれらの元素の植物体内での生理的活性の有無という点で注意すべきと考えられる。 
Appendix Mean concentrations of the different compartments. In each column, compartments sharing the same letter were not statistically significant different at the $1 \%$ level. The barks, roots and litter were not tested because of the low number of samples.

\begin{tabular}{|c|c|c|c|c|c|c|c|c|c|c|c|c|c|c|}
\hline \multirow{7}{*}{$\begin{array}{l}\text { leaves }{ }^{1} \\
\text { twigs }^{2} \\
\text { trunks }^{3}\end{array}$} & \multicolumn{4}{|l|}{$\%$} & \multicolumn{10}{|l|}{ ppm } \\
\hline & $\mathrm{N}$ & $\mathrm{K}$ & $\mathrm{Ca}$ & $\mathrm{Mg}$ & $\mathrm{Mn}$ & $\mathrm{Na}$ & $\mathrm{Al}$ & $\mathrm{Br}$ & $\mathrm{Fe}$ & B & $\mathrm{Sr}$ & $\mathrm{Ba}$ & $\mathrm{Zn}$ & $\mathrm{Rb}$ \\
\hline & $1.47^{\mathrm{a}}$ & $1.42^{\mathrm{a}}$ & $0.38^{\mathrm{a}}$ & $0.22^{\mathrm{a}}$ & $340.76^{\mathrm{a}}$ & $117.71^{\mathrm{a}}$ & $62.39^{a}$ & $45.12^{\mathrm{a}}$ & $38.93^{\mathrm{a}}$ & $25.16^{a}$ & $19.56^{\mathrm{a}}$ & $18.10^{\mathrm{a}}$ & $13.83^{\mathrm{a}}$ & $13.48^{\mathrm{a}}$ \\
\hline & $0.78^{b}$ & $1.14^{\mathrm{b}}$ & $0.61^{\mathrm{b}}$ & $0.20^{\mathrm{a}}$ & $305.62^{\mathrm{a}}$ & $118.03^{a}$ & ${ }^{a} 50.75^{a}$ & $14.93^{b}$ & $17.67^{b}$ & $11.03^{b}$ & $33.06^{b}$ & $32.44^{\mathrm{b}}$ & $33.02^{b}$ & $12.97^{\mathrm{a}}$ \\
\hline & $0.25^{\mathrm{c}}$ & $0.29^{\mathrm{c}}$ & $0.18^{\mathrm{c}}$ & $0.04^{\mathrm{b}}$ & $49.38^{b}$ & $98.98^{a}$ & $15.35^{\mathrm{a}}$ & $9.22^{\mathrm{ab}}$ & ${ }^{b} 11.23^{c}$ & $2.42^{\mathrm{c}}$ & $9.07^{\mathrm{C}}$ & $13.12^{\mathrm{c}}$ & $8.53^{\mathrm{c}}$ & $3.64^{b}$ \\
\hline & \multicolumn{14}{|l|}{$\overline{\mathrm{ppm}}$} \\
\hline & $\mathrm{Cu}$ & $\mathrm{Ni}$ & Co & $\mathrm{Ti}$ & $\mathrm{Sc}$ & $\mathrm{Cr}$ & $\mathrm{Pb}$ & $\mathrm{Ce}$ & $\mathrm{Li}$ & As & Cs & $\mathrm{V}$ & Mo & Th \\
\hline leaves $^{1}$ & $5.96^{\mathrm{a}}$ & $4.99^{\mathrm{a}}$ & $3.73^{\mathrm{a}}$ & $2.46^{\mathrm{a}}$ & $0.61^{\mathrm{a}}$ & $0.54^{\mathrm{a}}$ & $0.38^{\mathrm{a}}$ & $0.287^{\mathrm{a}}$ & $0.19^{\mathrm{a}}$ & $0.15^{\mathrm{a}}$ & $0.07^{\mathrm{a}}$ & $0.03^{\mathrm{a}}$ & $0.02^{\mathrm{a}}$ & $0.004^{\mathrm{a}}$ \\
\hline twigs $^{2}$ & $9.37^{\mathrm{b}}$ & $3.09^{\mathrm{b}}$ & $0.82^{\mathrm{b}}$ & $2.27^{\mathrm{a}}$ & $0.17^{b}$ & $0.27^{\mathrm{b}}$ & $0.34^{\mathrm{a}}$ & $0.015^{\mathrm{ab}}$ & ${ }^{b} 0.07^{b}$ & $0.05^{\mathrm{b}}$ & $0.09^{b}$ & $0.02^{\mathrm{b}}$ & $0.03^{\mathrm{a}}$ & $0.002^{b}$ \\
\hline trunks ${ }^{3}$ & $1.56^{\mathrm{c}}$ & $0.55^{\mathrm{c}}$ & $0.26^{\mathrm{c}}$ & $0.34^{\mathrm{b}}$ & $0.03^{c}$ & $053^{\mathrm{a}}$ & $0.68^{\mathrm{b}}$ & $0.004^{\mathrm{a}}$ & $0.02^{\mathrm{b}}$ & $0.03^{\mathrm{ab}}$ & $0.03^{\mathrm{c}}$ & $0.01^{\mathrm{c}}$ & $0.03^{\mathrm{a}}$ & $0.001^{\mathrm{c}}$ \\
\hline \multicolumn{15}{|c|}{${ }^{1} n=237^{2} n$} \\
\hline & \multicolumn{4}{|l|}{$\%$} & \multicolumn{10}{|l|}{ ppm } \\
\hline & $\mathrm{N}$ & $\mathrm{K}$ & $\mathrm{Ca}$ & $\mathrm{Mg}$ & $\mathrm{Mn}$ & $\mathrm{Na}$ & $\mathrm{Al}$ & $\mathrm{Br}$ & $\mathrm{Fe}$ & B & $\mathrm{Sr}$ & $\mathrm{Ba}$ & $\mathrm{Zn}$ & $\mathrm{Rb}$ \\
\hline barks ${ }^{4}$ & 0.58 & 0.77 & 0.30 & 0.16 & 34.46 & 62.28 & 233.50 & 18.40 & 122.00 & 6.56 & 21.94 & 42.49 & 9.06 & 9.96 \\
\hline roots 5 & 0.68 & 0.60 & 0.24 & 0.17 & 89.91 & 58.64 & 685.44 & 95.74 & 482.80 & 6.59 & 17.96 & 20.13 & 12.03 & 13.70 \\
\hline \multirow[t]{3}{*}{ litter $^{6}$} & 1.00 & 0.39 & 0.49 & 0.34 & 414.73 & 133.09 & 150.39 & 189.07 & 167.40 & 25.41 & 27.87 & 23.59 & 19.65 & 3.15 \\
\hline & \multicolumn{14}{|l|}{$\mathrm{ppm}$} \\
\hline & $\mathrm{Cu}$ & $\mathrm{Ni}$ & Co & $\mathrm{Ti}$ & $\mathrm{Sc}$ & $\mathrm{Cr}$ & $\mathrm{Pb}$ & $\mathrm{Ce}$ & $\mathrm{Li}$ & As & G & $\mathrm{V}$ & Mo & Th \\
\hline barks ${ }^{4}$ & 6.29 & 0.38 & 0.18 & 4.40 & 0.25 & 0.66 & 0.69 & 0.03 & 0.12 & 0.25 & 0.11 & 0.26 & 0.01 & 0.06 \\
\hline roots ${ }^{5}$ & 5.48 & 2.78 & 1.42 & 6.43 & 0.46 & 1.20 & 3.81 & 0.12 & 0.28 & 0.77 & 0.15 & 0.72 & 0.04 & 0.19 \\
\hline litter $^{6}$ & 10.55 & 3.74 & 0.45 & 3.48 & 1.17 & 1.82 & 1.11 & 0.03 & 0.06 & 1.11 & 0.05 & 0.22 & 0.05 & 0.02 \\
\hline
\end{tabular}

